JAMP: Jurnal Adminitrasi dan Manajemen Pendidikan

Volume 3 Nomor 2 Juni 2020, Hal : 141-151

Tersedia Online di http://journal2.um.ac.id/index.php/jamp/

ISSN 2615-8574 (online)

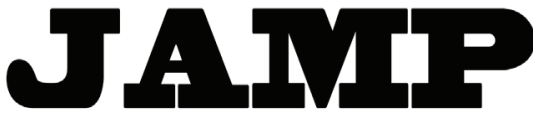

JURNAL ADMINISTRASI DAN MANAJEMEN PENDIDIKAN

\title{
EFEKTIVITAS PEMANFAATAN RUANG KELAS SEBAGAI SARANA PERKULIAHAN
}

\author{
Barson Robert Murib \\ Achmad Supriyanto \\ Asep Sunandar
}

Muribbarson1@gmail.com

SMK Negeri 1 Ilaga, Jalan Raya Gome Puncak Papua

\begin{abstract}
: the purpose of this study was to (1) determine the level of effectiveness of the use of lecture rooms for Education Administration students in each semester course in the 2018/2019 academic year; (2) knowing the level of effectiveness of the use of lecture rooms for Education Administration students in the classes of 2016, 2017 and 2018 in the even semester of the 2018/2019 academic year; and (3) knowing the level of effectiveness of the use of lecture halls for all Education Administration students in the even semester of the 2018/2019 academic year. The research method used is descriptive research with quantitative research types. The data analysis technique used is descriptive analysis. The results of the study are (1) the level of effectiveness of the use of lecture rooms for Education Administration students in each semester course in the 2018/2019 academic year including the high category; (2) the level of effectiveness of the use of lecture rooms for the 2016, 2017 and 2018 Education Administration students in the even semester of the 2018/2019 academic year is also in high category; (3) the level of effectiveness of the use of lecture halls for all Education Administration students in the even semester of the 2018/2019 academic year is also in the high category.
\end{abstract}

Keywords: Effectiveness; Use of Lecture Rooms; Department of Educational Administration.

\begin{abstract}
Abstrak: tujuan penelitian ini untuk (1) mengetahui tingkat efektivitas penggunaan ruang kuliah mahasiswa Administrasi Pendidikan tiap mata kuliah semester genap tahun akademik 2018/2019; (2) mengetahui tingkat efektivitas penggunaan ruang kuliah mahasiswa Administrasi Pendidikan angkatan 2016, 2017 dan 2018 pada semester genap tahun akademik 2018/2019; dan (3) mengetahui tingkat efektivitas penggunaan ruang kuliah seluruh mahasiswa Adminitrasi Pendidikan semester genap tahun akademik 2018/2019. Metode penelitian yang digunakan yaitu penelitian deskriptif dengan jenis penelitian kuantitatif. Teknik analisis data yang digunakan yaitu analisis deskriptif. Hasil penelitian adalah (1) tingkat efektivitas penggunaan ruang kuliah mahasiswa Administrasi Pendidikan tiap mata kuliah semester genap tahun akademik 2018/2019 termasuk kategori tinggi; (2) tingkat efektivitas penggunaan ruang kuliah mahasiswa Administrasi Pendidikan angkatan 2016, 2017 dan 2018 pada semester genap tahun akademik 2018/2019 juga dikatergori tinggi; (3) tingkat efektivitas penggunaan ruang kuliah seluruh mahasiswa Administrasi Pendidikan pada semeter genap tahun akademik 2018/2019 juga dikategori tinggi.
\end{abstract}

Kata Kunci: Efektivitas; Penggunaan Ruang Kuliah; Jurusan Administrasi Pendidikan.

Keberhasilan dalam proses belajar mengajar sangat di pengaruhi oleh berbagai hal, salah satu tersedia sarana dan prasaran yang memadai serta pemanfaat yang efektif dan efesien sehingga proses belajar mengajar pun dapat optimal (Direktorat Tenaga Kependidikan, 2007 :1). Manajemen sarana dan prasarana pendidikan dapat didefinisikan sebagai proses kerja sama pendayagunaan semua sarana dan prasarana pendidikan secara efektif dan efisien (Bafadal, 2008:2). Sehingga dapat diartikan bahwa saran dan prasarana pendidikan adalah segala sesuatu yang digunakan dalam proses pembelajaran. 
Sarana pendidikan dapat diartikan bahwa segala alat yang digunakan oleh peserta didik maupun guru dalam proses pembelajaran dan keberadaan alat itu pun tidak permanen. Permanen disini dimasudkan bahwa alat tersebut dapat dipindahkan, seperti papan tulis, kursi dan meja. Sarana sendiri berperan penting dalam membantu pemahaman peserta didik, seperti alat-alat peraga yaitu globe, kerangka manusia dan lain-lain. Adapun dengan lengkap sarana pendidikan diharapkkan peserta didik mampu memahami, menguasai materi yang diberikan guru kepada. Prasarana pendidikan merupakan segala sesuatu yang menunjang terjadi proses belajar mengajar. Prasaran sering tidak dirasakan keberadaan akan tetapi, prasarana amat berdampak besar kepada peserta didik maupun penyelenggara pendidikan. Seperti bangunan,lahan,uang semua menunjang pendidikan.

Prasaran dapat bermanfaat jika dapat dioptimalkan secara efektif dan efesien sehingga dapat tercapai tujuan pendidikan. Salah satu prasaran pendidikan yang sangat berperan penting dalam proses pembelajaraan ialah ruang kuliah. Ruang kuliah adalah suatu ruangan dalam bangunan lembaga pendidikan untuk kegiatan tatap muka dalam belajar dan mengajar. Menurut Ardi (2013 : 52), kelas adalah sebagai unit kerja terkecil di sekolah maupun di perguruan tinggi yang digunakan sebagai tempat untuk kegiatan belajar-mengajar. Jika dipergururan tinggi kelas lebih dikenal dengan ruang kuliah sedangkan di tingkat Sekolah Dasar (SD) sampai Sekolah Menengah Atas/Kejuruan (SMA/K) lebih dikenal dengan kelas. Kadang kala jika ruang kuliah bersih dan rapi berdampak pada semanggat mengajar dosen dan juga semangat mahasiswa dalam menerima pelajaran dari dosen, demikian sebalik jika kelas kotor dan berantakkan maka semangat mengajar dosen pun akan berkurang dan semangat belajar peserta didik juga menurun.

Adapun dalam mengukur efektivitas penggunaan ruang kuliah, peneliti mengacu pada jadwal penggunaan kuliah yang dikeluarkan oleh Kepala Sub Bagian Akademi Fakultas Ilmu Pendidikan Universitas Negeri Malang. Jadwal tersebut adalah pembagian penggunaan ruang kuliah oleh Kepala Sub Bagian dalam rangka pemanfaatan secara efektif dan efesien. Jadwal tersebut tertempel pada pintu setiap kelas dan terlihat bahwa jadwal seluruh kelas hampir terisi penuh, akan tetapi banyak ruang kuliah kosong yang seharus ruang kuliah tersebut digunakan sesuai dengan jadwal kuliah. Walaupun kelas tidak sepenuh digunakan secara efesien akan tetapi kelas dapat digunakan secara efektif oleh dosen dan mahasiswa dalam menunjang proses belajar dan mengajar.

Efektivitas merupakan kata yang digunakan untuk menggambarkan keberhasilan. Efektivitas berasal dari kata dasar efektif. Menurut Pasolong (2007:4) efektivitas berasal dari kata "efek" dan digunakan istilah ini sebagai hubungan sebab akibat. Efektivitas berarti bahwa tujuan yang telah direncanakan sebelum dapat tercapai atau dengan kata sasaran tercapai karena ada proses kegiatan. Efektivitas berdasarkan pendapat para ahli di atas dapat disimpulkan bahwa efektivitas adalah pengukuran berdasarkan standar atau rencana yang yang telah ditentukan. Penelitian ini menjadikan jadwal dan daftar hadir yang dikeluarkan oleh Kepala Sub Bagian Akademik sebagai standar dalam mengukur keefektivitasan penggunaan ruang kuliah sebagia sarana perkuliahan.

Penelitian mengenai penggunaan ruang kuliah juga pernah dilakukan oleh beberapa peneliti sebelumnya. Primanty pada tahun 2010 melakukan penelitian yang berjudul Analisis Okupansi Komputer di Laboratorium Komputer Fakultas Ilmu Pendidikan Universitas Negeri Malang yang bertujuan untuk mengetahui tingkat Occupancy Rate komputer, jumlah komputer yang rusak, dan jumlah komputer cadangan didapatkan hasil penelitian, yaitu penghitungan Occupancy Rate komputer diperoleh dari jumlah waktu yang dipergunakan dibagi dengan jumlah waktu yang disediakan selama satu bulan dan hasilnya dikalikan 100\%. Setyawan pada tahun 2017 juga melakukan penelitian tentang analisis okupansi yang berjudul Analisis Okupansi Ruang Kuliah Pada Fakultas Ilmu Pendidikan Universitas Negeri Malang yang bertujuan untuk mengetahui tingkat daya guna ruang kuliah pada FIP UM, untuk mengetahui tingkat okupansi tempat duduk di ruang kuliah pada FIP UM, untuk mengetahui kerugian dari tingkat okupansi yang tidak terpenuhi, dan untuk mendeskripsikan penyebab ruang kuliah tidak digunakan.

Penelitian ini dilaksanakan dengan tujuan untuk mengukur tingkat efektifitas penggunaan ruang kuliah oleh mahasiswa Administrasi Pendidikan berdasarkan daftar hadir yang telah disedikan oleh 
Kepala Subbagian Ajar Fakultas Ilmu Pendidikan. Penelitian ini dilaksanakan di Gedung D1 dan D2 kelas yang digunakan oleh mahasiwa Administrasi Pendidikan. Berdasarakan penggunaan ruang kuliah yang efektif namun tidak efesien tersebut peneliti berusaha mengkaji lebih dalam mengenai keefektivitas penggunaan ruang kelas di Jurusana Administrasi Pendidikan Fakultas Ilmu pendidikan Universitas Negeri Malang.

\section{METODE}

Penelitian ini menggunakan penelitian deskriptif dengan jenis penelitian kuantitatif. Alasan peneliti menggunakan penelitian kuantitatif karena data yang akan dikumpulkan yaitu berupa angka yang kemudian akan diolah untuk menemukan hasil dari tingkat efektivitas penggunaan ruang kuliah. Jenis desain penelitian yang digunakan, yaitu deskriptif, dimana peneliti mengumpulkan data atau fakta mengenai waktu penggunaan ruang kuliah pada saat peneliti melakukan penelitian, kemudian data tersebut diolah serta dianalisis dan dideskripsikan. Adapun variabelnya efektivitas penggunaan ruang kuliah itu sendiri sedangkan subvariabelnya adalah jumlah ruang kuliah, jadwal perkuliahan dan penggunaan ruang kuliah. Sumber data pada penelitian ini ada dua, yaitu sumber data primer dan sumber data sekunder.

Sumber data primer diperoleh dengan cara mengamati secara langsung penggunaan ruang kuliah di D1 dan D2. Sedangkan sumber data sekunder diperoleh dari petugas resepsionis D1 dan D2 serta dari dokumen penunjang.

Teknik pengumpulan data yang digunakan peneliti dalam penelitian ini, yaitu teknik observasi, wawancara, dan dokumentasi. Dalam teknik observasi, peneliti mengamati selama kegiatan belajarmengajar yang berlangsung di D1 dan D2. Peneliti mengamati berapa banyak ruang kuliah yang terpakai dan tidak terpakai serta berdasarkan jadwal yang telah dibagikan. Dalam teknik wawancara, peneliti memperoleh data dengan cara menggali informasi dari mahaiswa dan dosen. Wawancara dilakukan ketika apa yang dilihat belum sepenuhnya dapat memenuhi data yang diperlukan oleh peneliti. Wawancara yang dilakukan peneliti merupakan teknik wawancara informal atau tidak resmi, karena wawancara dilakukan di sela jam pelajaran berlangsung atau melalui chat di media sosial. Dalam teknik dokumentasi, peneliti melihat absensi yang telah diisi dan diserahkan kepada bagian akademik Fakultas Ilmu Pendidikan Universitas Negeri Malang. Peneliti juga meminta jadwal pelajaran kepada pegawai Kasubag Ajar Fakultas Ilmu Pendidikan Universitas Negeri Malang guna menyelaraskan antara presensi dengan jadwal yang seharusnya digunakan.

Teknik analisis data yang digunakan dalam penelitian ini yaitu analisis deskriptif yang didalamnya juga terdapat distribusi frekuensi berupa persentase. Analisis data dilakukan pada aplikasi microsoft excel, dimana peneliti membuat tabel kemudian memasukkan data waktu penggunaan yang diperoleh dari hasil penelitian yang dilakukan kemudian data tersebut dihitung menggunakan rumus efektivitas. Berikut rumus untuk menghitung efektivitas penggunaan ruang kuliah.

$$
\text { Efektivitas Ruang Kuliah }=\frac{\text { Realisasi Penggunaan Ruang Kuliah }}{\text { Rancangan Penggunaan Ruang Kuliah }} \times 100 \%
$$

Setelah diketahui persentase tingkat efektivitas ruang kuliahnya, maka ditarik kesimpulan untuk dikategori tingkat efektivitasnya. Kriteria penarikan kesimpulan yaitu menentukan panjang interval dari kategori tinggi, sedang, dan rendah. Berikut kriteria efektivitasnya.

Tabel 1. Kategori tingkat efektivitas

\begin{tabular}{cc}
\hline Nilai Kinerja & Keterangan \\
\hline$\geq 100 \%$ & Sangat Efektif \\
85 s.d. $99 \%$ & Efektif \\
65 s.d. $84 \%$ & Cukup Efektif \\
$\leq 65 \%$ & Tidak Efektif \\
\hline
\end{tabular}




\section{HASIL}

D1 dan D2 mayoritas digunakan oleh jurusan Bimbingan dan Konseling (BK), Teknologi Pendidikan (TEP), Administrasi Pendidikan (AP), Pendidikan Luar Sekolah (PLS), dan Pendidikan Luar Biasa (PLB). Lokasi kedua terletak di Jl. Raya Ki Ageng Gribig No.45, Madyopuro, Kec. Kedungkandang. Gedung kampus 2 yaitu B17 memiliki ruang kuliah sebanyak 12 ruangan yang ha digunakan oleh Jurusan PAUD dan PGSD sebagai sarana perkuliahan. Adapun kampus 2 ini ha digunakan oleh Fakultas Ilmu Pendidikan dan tidak digunakan oleh fakultas lain. Adapun penelitian ini dilakukan di gedung D1 dan Gedung D2 mengingat perkuliahan jurusan Administrasi Pendidikan ha di lakukan di gedung tersebut.

Deskripsi data penelitian ini ada yaitu efektivitas penggunaan ruang kuliah mahasiswa Administrisi Pendidikan tahun akademik 2018/2019 semester Genap. Awal peneliti berupaya untuk meneliti semua jurusan di Fakultas Ilmu Pendidikan namun karena sumber daya yang terbatas maka pemberi data hanya dapat memberikan data jurusan yang ditempuh oleh peneliti sendiri. Berdasarkan data yang dikumpulkan ini peneliti berusaha untuk memberikan jawaban sampel atas rumusan masalah, dan juga tujuan dari penelitian ini yaitu mengetahui seberapa besar tingkat efektivitas penggunaan ruang kuliah sebagai sarana pembelajaran. Adapun peneliti berasumsi bahwa mahasiswa mempunyai hak dalam menerima pembelajaran selama 16 pertemuan dalam sutu semester sesuai dengan Surat Keputusan yang dikeluarkan oleh Kasubag Ajar Universitas Negeri Malang, sehingga peneliti menyimpulkan bahwa hari libur (L) atau pun daftar hadir yang tidak diisi merupakan ketidak efektifan dalam menggunakan ruang kuliah sebagai sarana pembelajaran.

\section{Tingkat Efektivitas Penggunaan Ruang Kuliah Mahasiswa Administrasi Pendidikan Tiap Mata Kuliah Semester Genap Tahun Akademik 2018/2019}

Adapun dalam berdasarkan surat keputusan yang dikeluarkan oleh Kepala Sub Bagian Faakultas Ilmu Pendidikan Universitas Negeri Malang, bahwa Mahasiswa Administrasi Pendidikan menggunakan ruang kuliah selama 1 semester dengan 16 pertemuan dengan ruang kuliah yang telah ditentukan. Berdasarkan surat keputusaan tersebut dapat dilihat efektivitas penggunaan ruang kuliah sebagai tempat perkuliahan yang semestinya. Sehingga semakin sering digunakan semakin tinggi efektivitasnya. Berikut tingkat efektivitas penggunaan ruang kuliah tiap mata kuliah oleh mahasiswa Administrasi Pendidikan.

Tabel 2 Tingkat Efektivitas Penggunaan Ruang Tiap Mata Kuliah

\begin{tabular}{|c|c|c|c|c|}
\hline No & Mahasiswa Angkatan & Daftar Hadir & Kelas Tidak digunakan & Efektivitas (\%) \\
\hline 1 & 2016 & 1 & 0 & $100 \%$ \\
\hline 2 & & 2 & 0 & $100 \%$ \\
\hline 3 & & 3 & 0 & $100 \%$ \\
\hline 4 & & 4 & 0 & $100 \%$ \\
\hline 5 & & 5 & 0 & $100 \%$ \\
\hline 6 & & 6 & 0 & $100 \%$ \\
\hline 7 & & 7 & 0 & $100 \%$ \\
\hline 8 & & 8 & 1 & $93,75 \%$ \\
\hline 9 & & 9 & 0 & $100 \%$ \\
\hline 10 & & 10 & 1 & $93,75 \%$ \\
\hline 11 & & 11 & 0 & $100 \%$ \\
\hline 12 & & 12 & 0 & $100 \%$ \\
\hline 13 & & 13 & 0 & $100 \%$ \\
\hline 14 & & 14 & 1 & $93,75 \%$ \\
\hline 15 & & 15 & 0 & $100 \%$ \\
\hline 16 & & 16 & 0 & $100 \%$ \\
\hline 17 & & 17 & 0 & $100 \%$ \\
\hline 18 & & 18 & 0 & $100 \%$ \\
\hline
\end{tabular}




\begin{tabular}{|c|c|c|c|c|}
\hline No & Mahasiswa Angkatan & Daftar Hadir & Kelas Tidak digunakan & Efektivitas (\%) \\
\hline 19 & & 19 & 0 & $100 \%$ \\
\hline 20 & & 20 & 0 & $100 \%$ \\
\hline 21 & & 21 & 0 & $100 \%$ \\
\hline 22 & & 22 & 0 & $100 \%$ \\
\hline 23 & & 24 & 0 & $100 \%$ \\
\hline 24 & 2017 & 1 & 0 & $100 \%$ \\
\hline 25 & & 2 & 2 & $87,50 \%$ \\
\hline 26 & & 3 & 0 & $100 \%$ \\
\hline 27 & & 4 & 1 & 93,75 \\
\hline 28 & & 5 & 1 & $93,75 \%$ \\
\hline 29 & & 6 & 0 & $100 \%$ \\
\hline 30 & & 7 & 1 & $93,75 \%$ \\
\hline 31 & & 8 & 1 & $100 \%$ \\
\hline 32 & & 9 & 2 & $87,50 \%$ \\
\hline 33 & & 10 & 3 & $81,25 \%$ \\
\hline 34 & & 11 & 0 & $100 \%$ \\
\hline 35 & & 12 & 1 & $93,75 \%$ \\
\hline 36 & & 13 & 0 & $100 \%$ \\
\hline 37 & & 14 & 0 & $100 \%$ \\
\hline 38 & & 15 & 0 & $100 \%$ \\
\hline 39 & & 16 & 0 & $100 \%$ \\
\hline 40 & & 17 & 2 & $87,50 \%$ \\
\hline 41 & & 18 & 0 & $100 \%$ \\
\hline 42 & & 19 & 2 & $87,50 \%$ \\
\hline 43 & & 20 & 1 & $93,75 \%$ \\
\hline 44 & & 21 & 0 & $100 \%$ \\
\hline 45 & & 22 & 0 & $100 \%$ \\
\hline 46 & & 23 & 0 & $100 \%$ \\
\hline 47 & & 24 & 0 & $100 \%$ \\
\hline 48 & 2018 & 1 & 0 & $100 \%$ \\
\hline 49 & & 2 & 0 & $100 \%$ \\
\hline 50 & & 3 & 0 & $100 \%$ \\
\hline 51 & & 4 & 0 & $100 \%$ \\
\hline 52 & & 5 & 0 & $100 \%$ \\
\hline 53 & & 6 & 0 & $100 \%$ \\
\hline 54 & & 7 & 0 & $100 \%$ \\
\hline 55 & & 8 & 0 & $100 \%$ \\
\hline 56 & & 9 & 0 & $100 \%$ \\
\hline 57 & & 10 & 0 & $100 \%$ \\
\hline 58 & & 11 & 0 & $100 \%$ \\
\hline 59 & & 12 & 2 & $87,50 \%$ \\
\hline 60 & & 13 & 0 & $100 \%$ \\
\hline 61 & & 14 & 0 & $100 \%$ \\
\hline 62 & & 15 & 0 & $100 \%$ \\
\hline
\end{tabular}




\begin{tabular}{|c|c|c|c|c|}
\hline No & Mahasiswa Angkatan & Daftar Hadir & Kelas Tidak digunakan & Efektivitas (\%) \\
\hline 63 & & 16 & 1 & $93,75 \%$ \\
\hline 64 & & 17 & 1 & $93,75 \%$ \\
\hline 65 & & 18 & 0 & $100 \%$ \\
\hline 66 & & 19 & 0 & $100 \%$ \\
\hline 67 & & 20 & 0 & $100 \%$ \\
\hline 68 & & 21 & 0 & $100 \%$ \\
\hline 69 & & 22 & 0 & $100 \%$ \\
\hline 70 & & 23 & 0 & $100 \%$ \\
\hline 71 & & 24 & 0 & $100 \%$ \\
\hline
\end{tabular}

Tingkat Efektivitas Penggunaan Ruang Kuliah Mahasiswa Administrasi Pendidikan Angkatan 2016, 2017 dan 2018

Mahasiswa Angkatan 2016 memiliki 23 daftar hadir. Daftar hadir tersebut terdiri dari offering A,B dan C. Adapun jumlah alpa, izin, dan sakit merupakan jumlah keseluruhan mahasiswa bukan permahasiswa.

\section{a. Angkatan 2016}

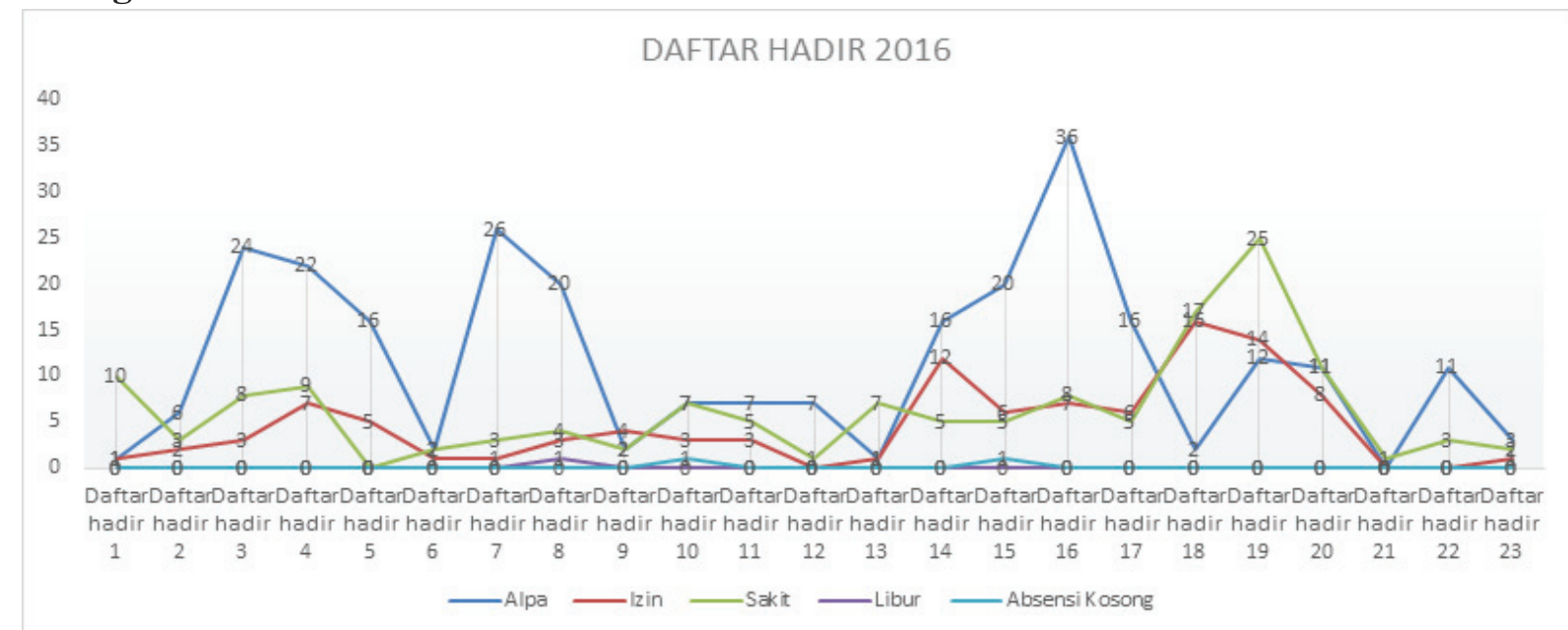

Gambar 1 Diagram Daftar Hadir Angkatan 2016

Berdasarkan digram di atas ditemukan:

1. Jumlah Alpa : 268

2. Jumlah Izin : 104

3. Sakit : 143

4. Libur : 1

5. Absen Kosong : 2

Adapun jumlah daftar hadir dan jumlah pertemuan angkatan 2016 adalah 16 pertemuan dan 23 jumlah daftar hadir, maka jumlah kehadiran angkatan 2016 adalah 368. Libur dan kelas tidak digunakan sebanyak 3. Maka efektivitas adalah:

$$
\frac{(368-3)}{368} \times 100 \%=99,18 \%
$$


Maka berdasarkan perhitungan tersebut peneliti menyimpulkan angkatan 2016 mnggunakan kelas secara sangat efektif.

\section{b. Angkatan 2017}

Mahasiswa Angkatan 2017 memiliki 23 daftar hadir. Daftar hadir tersebut terdiri dari offering A,B dan C. Adapun jumlah alpa, izin, dan sakit merupakan jumlah keseluruhan mahasiswa bukan permahasiswa.

\section{DAFTAR HADIR 2017}

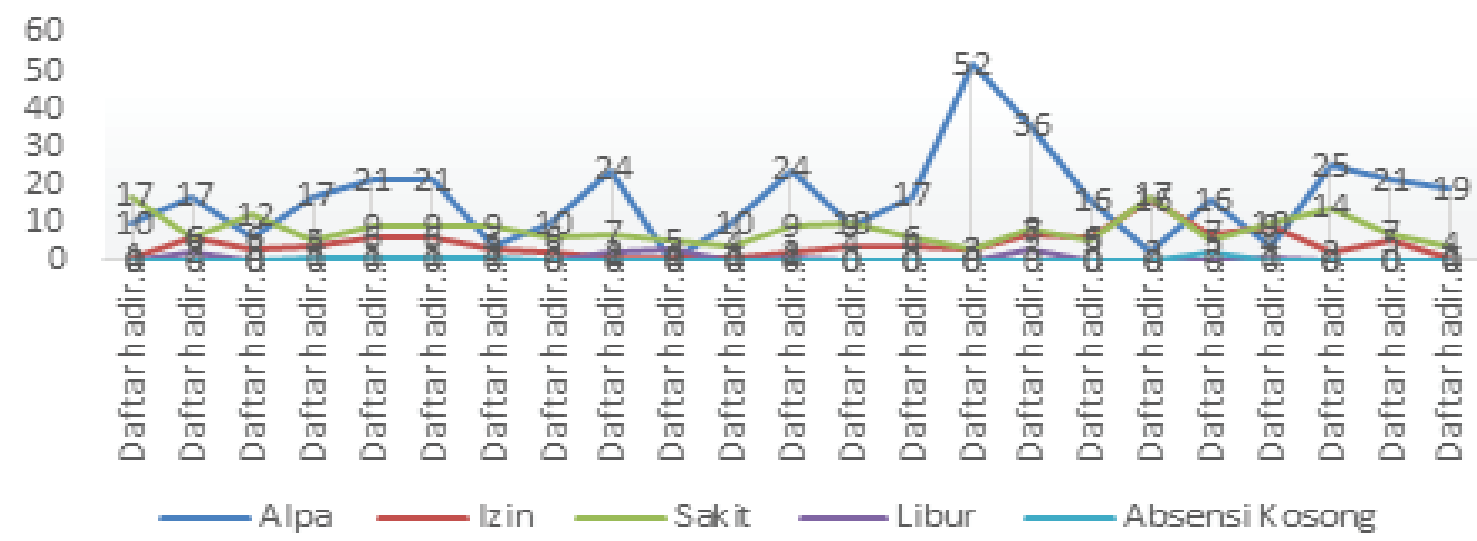

Gambar 2 Diagram Daftar Hadir Angkatan 2017

Berdasarkan digram di atas ditemukan:

1. Jumlah Alpa : 381

2. Jumlah Izin $\quad: 100$

3. Sakit : 187

4. Libur $: 12$

5. Absen Kosong : 6

Adapun jumlah daftar hadir dan jumlah pertemuan angkatan 2017 adalah 16 pertemuan dan 24 jumlah daftar hadir, maka jumlah kehadiran angkatan 2016 adalah 384. Libur dan kelas tidak digunakan sebanyak 16. Maka efektivitas adalah:

$$
\frac{(384-18)}{384} \times 100 \%=95,31 \%
$$

Maka berdasarkan perhitungan tersebut peneliti menyimpulkan angkatan 2017 mnggunakan kelas secara efektif.

\section{c. Angkatan 2018}

Mahasiswa Angkatan 2018 memiliki 24 daftar hadir. Daftar hadir tersebut terdiri dari offering A,B dan C. Adapun jumlah alpa, izin, dan sakit merupakan jumlah keseluruhan mahasiswa bukan permahasiswa. 


\section{DAFTAR HADIR 2018}

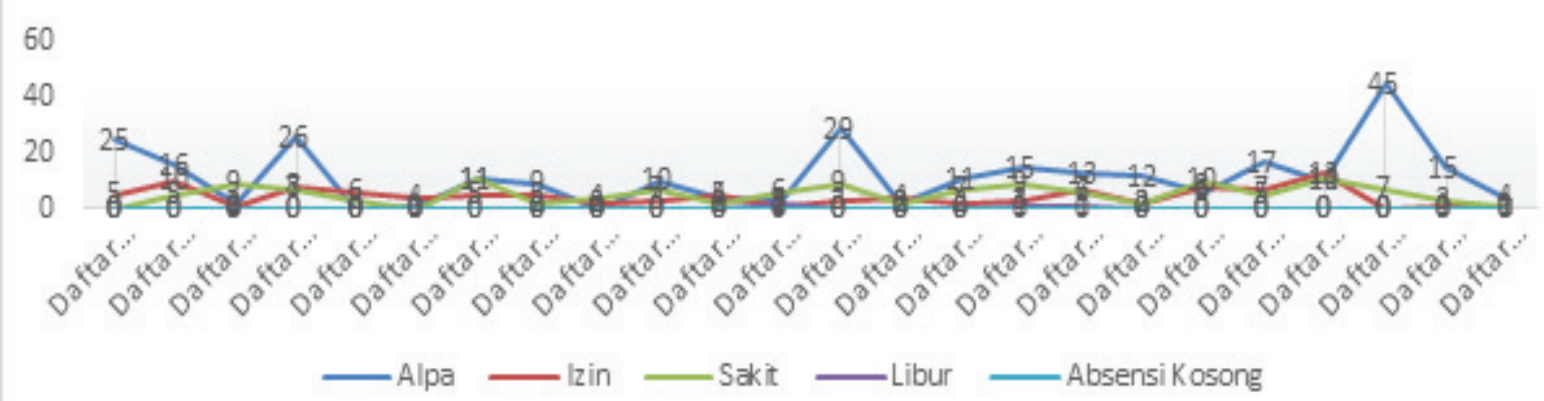

Gambar 3 Diagram Daftar Hadir Angkatan 2018

Berdasarkan digram di atas ditemukan:

1. Jumlah Alpa : 286

2. Jumlah Izin : 106

3. Sakit $: 128$

4. Libur : 4

5. Absen Kosong : 0

Adapun jumlah daftar hadir dan jumlah pertemuan angkatan 2017 adalah 16 pertemuan dan 24 jumlah daftar hadir, maka jumlah kehadiran angkatan 2017 adalah 384. Libur dan kelas tidak digunakan sebanyak 4. Maka efektivitas adalah:

$$
\frac{(384-4)}{384} \times 100 \%=96,96 \%
$$

Maka berdasarkan perhitungan tersebut peneliti menyimpulkan angkatan 2018 menggunakan kelas secara efektif.

\section{Tingkat Efektivitas Penggunaan ruang kuliah mahasiswa Administrasi Pendidikan Pada Semester Genap Tahun Akademik 2018/2019}

Adapun jumlah daftar hadir dan jumlah pertemuan angkatan 2016,2017 dan 2018 adalah 16 pertemuan dan 24 jumlah daftar hadir, maka jumlah kehadiran adalah 1.136. Libur dan kelas tidak digunakan sebanyak 22. Maka efektivitas adalah:

$$
\frac{(1.136-22)}{1.136} \times 100 \%=98,06 \%
$$

Maka berdasarkan perhitungan tersebut peneliti menyimpulkan angkatan 2016,2017 dan 2018 dalam menggunakan sudah efektif dalam menggunakan kelas ruang kuliah sebagai sarana perkuliahan

\section{PEMBAHASAN}

Mahasiswa Administrasi Pendidikan memiliki 2 gedung yang biasa digunakan untuk perkuliahan. Gedung yang digunakan ialah Gedung D1 dan Gedung D2, namun jika ada kuliah tamu bersama dengan jurusan lain maupun angkatan lain juga menggunakan Aula E1. Gedung D1 memiliki sebanyak 18 ruang kuliah dengan fasilitas di setiap ruang kuliah yang berbeda-beda. Gedung D2 memiliki sebanyak 8 ruang kuliah dengan fasilitas yang cukup memadai. Gedung kuliah dan fasilitas yang memadai yang dimiliki oleh mahasiswa Adminisitrasi pendidikan seharusnya dapat mendukung keefektivitas 
penggunaan ruang kuliah sebagai sarana perkuliahan bagi mahasiswa. Berdasarkan ketersediaan ruang kuliah yang memadai peneliti menyimpulkan bahwa libur dan daftar hadir yang tidak diisi merupakan ketidakefektifan penggunaan ruang kuliah sebagai sarana perkuliahan.

\section{Tingkat Efektivitas Penggunaan Ruang kuliah Mahasiswa Administrasi Pendidikan Tiap Mata Kuliah Semester Genap Tahun Akademik 2018/2019}

Berdasarkan Tabel 2 dapat diketahui bahwa selama 1 semester, tingkat efektivitas penggunaan ruang kuliah sebagai sarana perkuliahan sangat tinggi dengan tertinggi $100 \%$ dan terrendah $87,50 \%$. Adapun penyebab masih adanya mata kuliah/daftar hadir yang masih $87,50 \%$ dan $93,75 \%$ ini disebabkan oleh karena adanya libur nasional seperti 17 Agustus ( Hari Kemerdekaan Republik Indonesia), 20 Agustus ( Tahun Baru Islam 1442 Hijiriyah) dan lain-lain. Adapun mata kuliah yang bertabrakkan dengan hari libur tidak mengisi daftar hadirnya sehingga daftar hadir dihari itu kosong, namun ada juga beberapa mata kuliah yang dosennya berinisiatif menganti hari libur itu dengan hari lain sehingga dapat memaksilmalkan pembelajaran dan daftar hadir dapat diisi. Jadi, dapat disimpulkan bahwa tingkat efektivitas penggunaan ruang kuliah mahasiswa Administrasi Pendidikan tiap mata kuliah semester genap tahun akademik 2018/2019 termasuk kategori tinggi dikarenakan dari 71 hanya 12 daftar hadir yang belum mencapai target 16 pertemuan.

\section{Tingkat Efektivitas Penggunaan Ruang Kuliah Mahasiswa Administrasi Pendidikan Angkatan 2016, 2017 dan 2018}

Angakatan 2016 merupakan angkatan dengan efektivitas penggunaan ruang tertinggi di Jurusan Administrasi Pendidikan dari pada angkatan 2017 dan 2018, hal ini didukung dengan besarnya persentase efektivitas yang hampir sempurna yakni 99,18\% dan termasuk dalam kategori sangat efektif. Sedangkan untuk 2017 menjadi angkatan yang terrendah efektivitasnya dalam pemanfaatan ruang kelas sebagai sarana perkuliahan dengan persentase $95,31 \%$ dan termasuk kategori efektif. Adapun angkatan 2018 memperoleh 98,96\% dengan kategori efektif. Perhitungan 99,18\% , 95,31\% dan 98,96\% dilakukan sesuai dengan teori yang dijelaskan oleh Mahmudi ( 2007:111) bahwa dalam mengukur efektivitas dirumuskan realisasi penggunaan ruang kuliah dibagi dengan rancangan penggunaan ruang kemudian dikali $100 \%$ sehingga diperoleh persentase efektivitas penggunaan ruang kuliahnya. Sedangkan, untuk pengkategoriannya juga merujuk pada Mahmudi ( 2007) yang membagi kriteria efektivitas yang terdiri dari $\geq 100 \%$ dikategori sangat efektif, $85 \%$ sampai dengan $99 \%$ efektif, $65 \%$ sampai dengan $84 \%$ cukup efektif dan $\leq 65 \%$ tidak efektif.

\section{Efektivitas Penggunaan Ruang Kuliah Mahasiswa Administrasi Pendidikan Tahun Akademik Genap 2018/2019}

Berdasarkan gambar 1, 2 dan 3 penggunaan kelas oleh mahasiswa Administrasi Pendidikan tiap mata kuliah dari angkatan 2016 sampai dengan 2018 rata-rata efektif dalam menggunakan ruang kelasnya secara efektif. Adapun penggunaan ruang kuliah yang paling sedikit adalah daftar hadir 10 dengan efektivitasnya mencapai $81,25 \%$. Sedangkan, selebihnya ada yang $87,5 \%, 93,75 \%$ dan $100 \%$.

Penggunaan ruang kuliah yang dilakukan oleh angkatan 2016,2017 dan 2018 yang mencapai 99,18\%, 95,31 dan 98,96\% dikategorikkan efektif, hal ini juga didukung oleh Soetopo (1986:50) yang dalam bukunya menjelaskan bahwa ukuran efektivitas dalam suatu penggunaan ruang kuliah bila mana apa yang direncakan atau ditargetkan dapat dilaksanakan atau tercapai. Adapun jumlah daftar hadir dan jumlah pertemuan angkatan 2016,2017 dan 2018 adalah 16 pertemuan dan 24 jumlah daftar hadir untuk angkatan 2017 dan 2018 sedangkan 23 untuk angkatan 2016 maka jumlah kehadiran adalah 1.136. Libur dan kelas tidak digunakan sebanyak 22. Maka berdasarkan perhitungan tersebut peneliti menyimpulkan anggkatan 2016,2017 dan 2018 menggunakan kelas secara efektif. Berdasarkan data yang diperoleh dari tiap kelas sampai dengan tingkat jurusan diperoleh lebih 98,06\%. Adapun menurut Mahmudi (2007) 98,06\% cukup efektif dalam menunjukkan bahwa mahasiswa dan dosen Administrasi Pendidikan dalam menggunakan ruang kuliahnya selama 1 semester.

Jurusan Administrasi Pendidikan Pendidikan dalam mengunakan ruang kuliah secara efektif namun ditemukan beberapa fakta bahwa tingkat alpa masih sangat tinggi dibeberapa daftar hadir tersebut. 
Alpa di angkatan 2018 tertinggi mencapai 45 alpa, angkatan 2017 tertinggi 52 dan 2016 mencapai 36 sehingga sangat memprihatinkan sekali. Adapun apla ditiap kelas ini disebabkan oleh salah satu mahasiswa maupun serentak oleh beberapa mahasiswa dalam hari yang sama. Berdasarkan wawancara dengan mahasiswa maupun dengan dosen mata kuliah ditemukan beberapa faktor penyebab terjadi alpa yakni terlambat bangun, lupa kalau ada kuliah, ada kegiatan organisasi dan tidak meminta izin tidak mengikuti perkuliahan. Salah satu penyebab mahasiswa alpa bak dihari yang sama adalah kesalahan komunikasi yang dibangun mahasiswa dengan dosen, seperti mahasiswa menunggu di kelas 15 menit namun karena dosen tidak kunjung datang maka mahasiswa meninggalkan kelas, sehingg bak yang alpa.

\section{SIMPULAN}

Angkatan 2016 mahasiswa Administrasi pendidikan tergolong efektif dalam menggunakan ruang kuliah sebagai sarana perkuliahan. Efektivitas mencapai 99,18\% sehingga disimpulkan efektif dalam menggunakan ruang kuliah. Adapun tingkat alpa angkatan ini tertinggi mencapai 36 apla dan terendah 0 , sehingga diharapkan di semester berikut efektivitas dipertahankan dan tingkat apla bisa dikurangi.

Mahasiswa angkatan 2017 Jurusan Administrasi Pendidikan tergolong masih cukup efektif dalam menggunakan ruang kuliah sebagai sarana perkuliahan. efektivitas mencapai 95,31\% sehingga dianggap masih cukup efektif dalam menggunakan ruang kuliah. Adapun tingkat apla angkatan adalah tertinggi dari semua angkatan yakni 52 dan terendah yakni 0, sehingga diharapkan tingkat efektivitas di semester mendatang dapat lebih ditingkatkan dan juga perlu diperhatikan tingkat alpa.

Angkatan 2018 merupakan angkatan paling muda di Jurusan Administrasi Pendidikan di semeter genap 2018/2019. Efektivitas angkatan 2018 mencapai 98,96\% ssehingga dapat disimpulkan masih efektif dalam menggunakan ruang kuliah sebagai sarana perkuliahan. Adapun tingkat alpa tertinggi mencapai 45 dan terendah 0 , sehingga dapat harapkan semester mendatang dapat mempertahankan efektivitas penggunaan kelas dan mengurangan tingkat alpa .

Jurusan Administrasi Pendidikan angkatan 2016,2017 dan 2018 mencapai 98,06\% yang tergolong efektif. Walapun pengunaan kelas efektif namun perlu diperhatikan tingkat alpa yang mencapai 936 alpa, adapun apla ini lebih bak dilakukan oleh perorangan maupun dilakukan oleh beberapa orang dalam jangka waktu yang bersamaan. Sakit dan Izin pada semeter itu pun dibawah tingkat apla yakni 458 dan 310, sehingga diperlukan kajian lebih lanjut mengenai ketidak hadir mahasiswa tanpa keterangan lebih lanjut.

\section{DAFTAR RUJUKAN}

Arikunto, S. 2002. Prosedur Penelitian Suatu Pendekataan Praktek. Jakarta: PT Ashi Mahasatya. Ardi, N.W. 2013. Manajemen Kelas. Yogjakarta: Ar-Ruzz Media.

Bafadal, I. 2008. Manajemen Perlengkapan Sekolah: Teori dan Aplikasi. Jakarta: Bumi Aksara.

Badan Standar Nasional Pendidikan. 2006. Standar Isi. Badan Standar Nasional Pendidikan: Jakarta.

Barnawi \& Arifin, M. 2012. Manajemen Sarana dan Prasarana. Jogjakarta: Arruzz Media.

Badan Standar Nasional Pendidikan. 2011. Jakarta: Bumi Aksara.

Bungin, Burhan. 2013. Metodologi Penelitian Kuantitatif. Jakarta: Kencana Prenada Media Group.

Faiz R. B. dan Eran A., Decision Making for Predictive Maintenance in Asset Information Management, Edirisinghe Department of Computer Science, Loughborough University, Leicestershire, UK, Interdisciplinary

Handayaningrat, S1983. Pengantar Studi Ilmu Administrasi dan Manajemen. Jakarta: Gunung Agung.

Hendyat, S \& Wasyti. S, 1986. Pembinaan dan Pengembangan Kurikulum. Jakarta: Bina Aksara.

Kusumastuty, Karina .D. 2016. Prospek Analisi Post Occupancy Evaluation (POE) sebagi Tinjaun untuk Mengevaluasi Perfoma Ruan terbuka Hijau Publik di Perkotaan. TEMU ILMIAH IPLBI 2016, 78. DOI: http://temuilmiah.iplbi.or.id/wp-content/uploads.

Mahmudi. 2007. Manajemen Kinerja Sektor Publik.. Yogyakarta: UPP STIM YKPN.

Munawaroh, K. 2013. Metodelogi Penelitian. Malang: Intimedia

Mulyasa. E. 2007. Manajemen Berbasis Sekolah. Bandung: PT. Remaja Rosdakarya. 
Pasolong, Harbani. 2007. Teori Administrasi Publik. ALFABETA.

Phelupesik, Milany 2009 Perancangan Ruang Kelas Dengan Pendekatan Ergonomi Di Sekolah Alkitab Teologia Indonesia (SATI) Malang.(Undergraduate Thesis). DOI : http://repository.ubaya.ac.id/25923/.

Ulfatin, N. 2015. Metodelogi Penelitian Kualitatif di Bidang Pendidikan: Teori dan Aplikasi. Malang: Media Nusa Creative.

Saukah, Ali. B dan Imam. B. 2017. Pedoman Penulisan Karya Ilmiah: Universitas Negeri Malang.

Setyadin, B. 2005. Desing dan Metode Penelitian Kuantatif, (modul IV). Malang: Lembaga Penelitian Universitas Negeri Malang.

Siagian, S.P. 1978. Manajemen. Yogyakarta: Liberty.

Sunandar, A. 2015. Exploring of School Asset. International Conference on Education and Tarining (ICET) 2015, 35. DOI: http://ap.fip.um.ac.id/wp-content.

Sugiyono. 2014. Metode penelitian Kuantitatif Kualitatif \& $R \&$ D. Bandung: Alfabeta.

Wiyono, B.B. 2007. Metodelogi Penelitian Kuantitatif dan action Reseach. Malang: Fakultas Ilmu Pendidikan Universitas Negeri Malang. 